\title{
GLIWICE RADIOCARBON DATES XI
}

\section{MIECZYSLAW F. PAZDUR, ROMUALD AWSIUK, TOMASZ GOSLAR, ANNA PAZDUR ADAM WALANUS and ANDRZEJ ZASTAWNY}

Radiocarbon Laboratory, Institute of Physics, Silesian Technical University, Krzywoustego 2 PL-44-100 Gliwice, Poland

\section{INTRODUCTION}

The following list presents results of dating archaeological samples from Poland processed between 1979 and 1985. Three carbon dioxide-filled proportional counters (L1, L2 and L3) of different sizes were used for dating (Pazdur et al. 1982). Procedures for sample pretreatment, counting, statistical analysis and age calculations were essentially the same as previously described (Pazdur et al. 1982, 1985). All results are reported as conventional ${ }^{14} \mathrm{C}$ dates in years before $\mathrm{AD} 1950$. Unless explicitly stated, the results are not corrected for isotopic fractionation.

\section{ACKNOWLEDGMENTS}

Most dates included in this list were made for the Research Project MR.III.5 coordinated by the Institute of History of Material Culture, Polish Academy of Science. This contribution was made possible by grant PB 740/6/91 from the State Committee for Scientific Research.

\section{THE PALEOLITHIC AND MESOLITHIC}

\section{Rydno Series}

Charcoal from various units of a hematite mine in Rydno $\left(51^{\circ} 5^{\prime} \mathrm{N}, 21^{\circ} 10^{\prime} \mathrm{E}\right)$, Nowy Mlyn Village, Kielce district, foothills of Holy Cross Mts. Dated to establish main phases of hematite exploitation, lasting from the Late Paleolithic until the Roman period (Schild and Krolik 1981). Submitted 1982 by R. Schild, Institute of Archaeology and Ethnology, Polish Academy of Sciences, Warsaw.

Gd-710. Rydno Trench I/1977

$10,630 \pm 320$

Small pieces scattered at base of Shaft 1 at depth $88-95 \mathrm{~cm}$; collected 1977 by J. Moscibrodzka.

Comment (R.S.): Associated with the Masovian cycle dated to the Younger Dryas; expected age, $8800-7800 \mathrm{BC}$. Charcoal from hearth in uppermost part of same shaft dated to $1510 \pm 55 \mathrm{BP}$ : Bln-2036.

Gd-713. Rydno Trench III/1979 \#1

$10,910 \pm 220$

Scattered chips from the oldest phase of fill from the Great Opening consisting of conglomerates, depth $50-80 \mathrm{~cm}$. All samples from Trench III/1979 collected 1979 by M. Marczak.

Comment (R.S.): No associated cultural material.

Gd-719. Rydno Trench III/1979 \#2

$9840 \pm 370$

Small pieces from fill of the Little Opening; depth $44 \mathrm{~cm}$.

Gd-724. Rydno Trench III/1979 \#3

Small pieces from the 2 nd phase of fill from the Great Opening consisting of sandy conglomerates; depth $70-80 \mathrm{~cm}$. 
Gd-714. Rydno Trench III/1979 \#4

$10,710 \pm 250$

From a concentration of charcoal at the base of sandy fill from the Great Opening, depth $145 \mathrm{~cm}$.

Gd-725. Rydno Trench III/1979 \#5

$12,290 \pm 210$

From a concentration of charcoal at the base of sandy conglomerate fill from the Great Opening; depth 90-110 cm.

Gd-2003. Rydno I/1976

$3560 \pm 80$

From a dwelling pit containing alluvial sediment with an admixture of hematite dust; depth 55-70 cm. Collected 1976.

Gd-1519. Rydno I/1981

$2660 \pm 60$

From the fill of spaces between sandstone blocks marking the contour of a hearth; depth 70-110 cm. Collected July 1981 by H. Królik.

Gd-2002. Rydno I/1980 \#12

$19,280 \pm 280$

From a concentration of charcoal in an exploitation pit consisting of many units; depth 105-120 $\mathrm{cm}$. Collected July 1980 by M. Marczak.

Comment (R.S.): Expected age: Late Paleolithic, ca. 12,500 BP.

Gd-3207. Rydno-Grzybowa Gora IV/1947

$8180 \pm 60$

Charcoal from a small pit in the B horizon of Podzol in subsurface site Rydno-Grzybowa Góra (Schild 1975). Collected July 1947 by S. Krukowski, submitted 1985 by R. Schild.

\section{Całowanie Series}

Single fragments of partly burned wood from Late Paleolithic cultural layers at the edge of a dune at contact with a peat bog in Całowanie $\left(52^{\circ} 6^{\prime} \mathrm{N}, 21^{\circ} 14^{\prime} \mathrm{E}\right)$, south of Otwock, Warsaw district. Całowanie is a key site for interdisciplinary studies of the Final Paleolithic in Poland. It is located in the center of an abandoned channel of the Vistula River filled with thick beds of peat and some sandy islands with traces of human occupation. Results of the first interdisciplinary studies in Całowanie, conducted by R. Schild over several seasons (1963-1969) were summarized by Schild (1982) and Dąbrowski (1981). Samples from Trench VII/1966 collected 1966 and from Trench X/1983 collected July 1983 and submitted 1983 by R. Schild.

Gd-1648. Całowanie \#1A

Gd-2147. Całowanie \#1B

$10,140 \pm 80$

Two parts of the same sample from Trench X/1983, Level 9b; depth $165 \mathrm{~cm}$.

$10,030 \pm 120$

Gd-1662. Całowanie \#2

From Trench X/1983, top of Level $9 \mathrm{~b}$ at contact with base of Level 11a; depth $150 \mathrm{~cm}$.

Gd-1667. Całowanie \#3A

Gd-1668. Całowanie \#3A

$8780 \pm 80$

Gd-2146. Całowanie \#3C

$8640 \pm 80$

Individual pieces of charcoal or charred wood from Trench X/1983, the topmost part of Level 11b, cultural layer VII; depth $75 \mathrm{~cm}$.

Gd-2149. Całowanie \#4A

Gd-1670. Całowanie \#4B

$9080 \pm 100$

From Trench X/1983, the base of Level 11a, overlying cultural layer VII; depth $70 \mathrm{~cm}$. 
Gd-1669. Całowanie \#5

$2610 \pm 40$

A small pale with traces of artificial treatment, Trench X/1983, top of Level 11a, cultural layer VIII; depth $50 \mathrm{~cm}$.

Gd-1717. Całowanie \#6

$9700 \pm 80$

Trench VII/1966, Level 11b, cultural layer VII; depth $127 \mathrm{~cm}$.

Gd-1719. Całowanie \#7

$9370 \pm 60$

Same location; depth $120 \mathrm{~cm}$.

Gd-2198. Całowanie \#8

$9350 \pm 100$

Same location; depth $120 \mathrm{~cm}$.

Gd-3041. Całowanie \#9

$9030 \pm 50$

Same location; depth $147 \mathrm{~cm}$.

Gd-1721. Całowanie \#10

$9380 \pm 80$

Same location; depth $140 \mathrm{~cm}$.

Comment (R.S.): This series supplements earlier ${ }^{14} \mathrm{C}$ dates of charcoal or charred wood obtained in Groningen. The dates, in stratigraphic order, are as follows: base of Level 9b: 10,455 \pm 90 , GrN5049; near top of Level 9b: $9935 \pm 110$, GrN-5254; base of Level 11b: $9250 \pm 55$, GrN-5251 and $9200 \pm 75$, GrN-5442; topmost part of Level 11a: $8360 \pm 75$, GrN-5966.

\section{Chwalim Series}

Wood and charcoal from a peat bog situated close to a Mesolithic settlement, Site 1 on a terrace of the Gniła Obra River in Chwalim $\left(52^{\circ} 7^{\prime} \mathrm{N}, 15^{\circ} 55^{\prime} \mathrm{E}\right)$ near Kargowa, Zielona Góra district, Great Poland Lowland. Collected July 1979 and submitted 1979 by M. Kobusiewicz, Institute of the History of Material Culture, Polish Academy of Sciences, Poznan.

Gd-1164. Chwalim 1 WKT III/79 \#1

Charcoal from a layer of brown undecomposed peat at the base of a peat bog adjacent to an older terrace with a Mesolithic settlement, Trench III/79; depth 190-200 cm.

Gd-1165. Chwalim 1 WKT III/79 \#2

$9450 \pm 80$

Wood from a large tree trunk found at the base of a peat bog, same locality; depth $165 \mathrm{~cm}$.

Gd-1176. Chwalim 1 WKT II/79 \#1

$4630 \pm 70$

Fragments of a partly burned shingle found in a layer of black peat mixed with charcoal dust at the base of a peat bog adjacent to a younger terrace with a Neolithic settlement, Trench II/79; depth 210$220 \mathrm{~cm}$.

Comment (M.K.): Charcoals from layer associated with Mesolithic settlement were dated to $9500 \pm$ 75: Bln-1766; charcoal from layer associated with a Neolithic settlement was dated to $3900 \pm 50$ : Bln-1767; $4280 \pm 45 ; \mathrm{Bln}-2019$; and $4375 \pm 50$ : Bln-2018 (Kobusiewicz 1980).

\section{Gd-389. Krzekótowek K-8-I/72}

$6880 \pm 190$

Charcoal from a hearth in a Mesolithic dwelling in Krzekotówek $\left(51^{\circ} 42^{\prime} \mathrm{N}, 16^{\circ} 18^{\prime} \mathrm{E}\right)$, near Głogów, on a dune covering a terrace of the Krzycki Rów River. Collected 1972 and submitted 1976 by Z. Bagniewski.

Comment (Z.B.): Date agrees well with archaeological dating to the beginning of the Atlantic phase. 
Gd-2432. Janisławice J1

$6580 \pm 80$

Bone collagen from a Mesolithic grave in Janisławice $\left(51^{\circ} 40^{\prime} \mathrm{N}, 20^{\circ} 5^{\prime} \mathrm{E}\right)$, near Gruchów, Skierniewice district. Collected 1937 by K. Jażdżewski; submitted 1985 by Z. Sulgostowska, State Archaeological Museum, Warsaw.

Comment (Z.S.): Expected age: 7th/6th millennium BC (Chmielewska 1954).

\section{Ełk Series}

Charcoal from Site I in Ełk (53 49 N, 22 20'E), Mazury Lakeland, northeast Poland. Collected 1970 and submitted 1982 by J. Trzeciakowski, Institute of the History of Material Culture, Polish Academy of Sciences, Warsaw.

Gd-1527. Ełk $\mathrm{I} / \mathbf{1}$

$6310 \pm 70$

From a hearth in a cultural layer at depth $30-50 \mathrm{~cm}$, associated with Late Paleolithic/Mesolithic artifacts.

Gd-1546. Ełk I/2

Dispersed in cultural layer, Trench 2; depth $20-40 \mathrm{~cm}$.

$3050 \pm 50$

\section{Gojść Series}

Charcoal from an open Paleolithic site on terrace of Warta River in Gojść $\left(51^{\circ} 4^{\prime} \mathrm{N}, 19^{\circ} 10^{\prime} \mathrm{E}\right)$, Kraków-Wieluń Upland, Czętochowa district. Collected and submitted 1983 by Bolesław Ginter, Institute of Archaeology, Jagellonian University, Kraków.

Gd-1642. GI/81/30-35 cm

$2260 \pm 40$

Hearth in Trench I; depth $30-35 \mathrm{~cm}$.

Gd-1643. GII/81/30 cm

Hearth in Trench II; depth $30 \mathrm{~cm}$.

$990 \pm 50$

Gd-2122. GIII/81/30-50 cm

Hearth in Trench III; depth 30-50 cm.

$1290 \pm 80$

Gd-2123. GIII/81/100 cm

Hearth in Trench III; depth $100 \mathrm{~cm}$.

$4020 \pm 90$

Gd-2124. G-S/5/100-130 cm

$4030 \pm 90$

Hearth in Trench S/5; depth 100-130 cm.

Comment (B.G.): The site is associated with the exploitation of a flint mine of the Swiderian culture; expected age: $8-9 \mathrm{kyr}$ BP. Dates are much younger than expected.

\section{NEOLITHIC}

\section{Wożna Wieś Series}

Bone and charcoal from Site I of a hunting and harvesting group (Kempisty and Sulgostowska $1976)$, situated on a lake terrace in Wożna Wieś $\left(53^{\circ} 45 \mathrm{~N}, 22^{\circ} 45^{\mathrm{E}}\right.$ ), Łomża district, Mazury Lakeland, northeast Poland. Collected 1974 and 1978 and submitted 1984 by Z. Sulgostowska.

\section{Gd-2431. W I/3/74}

$5900 \pm 100$

Collagen from a human bone from a single skeleton found at depth 30-90 cm, Trench 3, Square 11 . 
Gd-3134. WW I/1/78

$2990 \pm 50$

Charcoal from a hearth (?), Trench 1; depth 60-90 cm.

Gd-2429. Firlus 8/10/4

$6020 \pm 100$

Charcoal from cultural layer 4 at the base of Pit 4 , Trench 10, depth $70-80 \mathrm{~cm}$, Site 8 in Firlus $\left(53^{\circ}\right.$ $\left.16^{\prime} \mathrm{N}, 18^{\circ} 38^{\prime} \mathrm{E}\right)$ on E shore of Młyńskie Lake, near Popowo Biskupie, Toruń district, Chełmińskie Lakeland. Collected 1983 and submitted 1984 by R. Kirkowski, Regional Museum, Grudziądz.

Comment (R.K.): Dated to establish a chronology for the Bandkeramik culture in the region of Chełmińskie Lakeland; expected age: 3600-3800 BC (Czerniak 1980).

\section{Dęby Series}

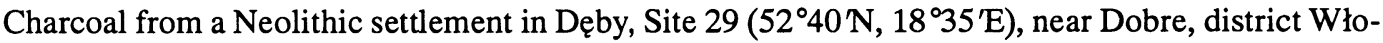
cławek, Kujawy Plateau.

Gd-2148. D29/32-186

$4600 \pm 90$

From the basal part of Object 32 of worship type; depth $30-50 \mathrm{~cm}$. Collected 1983 by J. Czebreszczuk and submitted by A. Kośko.

Comment (A.K.): Sample dates cultural disintegration in the Late Neolithic and the first occurrence of typical features of Bronze Age cultures in the Kujawy region (Kośko 1981a).

Gd-2278. D29/84 \#1

$7250 \pm 100$

Single fragments of charcoal from a pit made by a pole of a Neolithic cottage, Trench VII; depth $60 \mathrm{~cm}$. Collected July 1984 by L. Domańska; submitted August 1984 by A. Kośko.

Comment (A.K.): Dates influences of Janisławice culture; expected age: 4th millennium BC.

Gd-1928. D29/85 \#3

$6090 \pm 70$

Charcoal dispersed in the vestibule of a Neolithic cottage; depth 60-70 cm. Collected July 1985 by L. Domańska; submitted October 1985 by A. Kośko.

Comment (A.K.): Sample from the same cultural level as Gd-2278.

Gd-2482. D29/85 \#4

$7940 \pm 80$

From a hearth belonging to a Late Mesolithic habitation, Trench XV/XX; depth 80-90 cm. Collected July 1985 and submitted 1986 by L. Domańska.

\section{Białcz Stary Series}

Charcoal from a Neolithic settlement in Białcz Stary $\left(52^{\circ} 20 \mathrm{~N}, 16^{\circ} 40^{\prime} \mathrm{E}\right)$, Site 4 , near Smigiel, Leszno district, Great Poland Lowland. Collected by L. Czerniak; submitted by T. Wiślański, Institute of the History of Material Culture, Polish Academy of Sciences, Poznań.

Gd-2054. BS 4/46

$5820 \pm 80$

Charcoal (Pinus sp., identified by K. Surmiński) from layer in upper part of Pit 46 belonging to Stroked Pottery culture, depth 90-100 cm. Collected June 1980.

Gd-1608. BS 4/109Be

$5340 \pm 70$

From the base of Pit 109Be of the late phase of the Bandkeramik culture (Czerniak 1980), depth $60-80 \mathrm{~cm}$. Collected July 1982.

Gd-1753. BS 4/154

$5860 \pm 50$

From the base of Pit 154 . 


\section{Dąbrowa Biskupia Series}

Charcoal from large Neolithic settlement in Dabrowa Biskupia, Site $21\left(52^{\circ} 46^{\prime} \mathrm{N}, 18^{\circ} 32^{\prime} \mathrm{E}\right)$, district Bydgoszcz, Kujawy Plateau. Collected 1984 by M. Szmyt and submitted by A. Kośko.

Gd-2277. DB 21-81/90A

$8500 \pm 110$

From depth $60 \mathrm{~cm}$, the base of Object 81/90.

Gd-2289. DB 21-92a

From the central part of Object 92; depth $c a .70 \mathrm{~cm}$.

$4400 \pm 140$

Gd-1929. DB 21-81/90BB

$7920 \pm 70$

From a collection of charcoal (hearth?) at the edge of a large half-dugout; depth $92-114 \mathrm{~cm}$. Collected 1983 by P. Chachlikowski.

Gd-2509. Węgierce 12/1

$5860 \pm 100$

Scattered fragments of bone from depth 1.1-1.5 m, Pit 1 of an early Neolithic settlement, Site 12 in Węgierce $\left(52^{\circ} 45^{\prime} \mathrm{N}, 18^{\circ} 9^{\prime} \mathrm{E}\right)$ near Janikowo, district Bydgoszcz, Kujawy Plateau. Collected July 1985 by M. Szmyt; submitted December 1985 by A. Kośko.

Comment (A.K.): Associated archaeological material indicates Phase $1 \mathrm{~b}$ of the Late Bandkeramic culture; the date fits with expected age: $3800-3700 \mathrm{BC}$.

\section{Opatowice Series}

Charcoal from a Neolithic settlement in Opatowice, Site $33\left(52^{\circ} 43 \mathrm{~N}, 18^{\circ} 33^{\circ} \mathrm{E}\right)$ near Radziejów, district Włocławek, Kujawy Plateau.

Gd-2287. Opatowice 33-3A

$6190 \pm 120$

From a half-dugout, Object 3, depth $c a .80 \mathrm{~cm}$. Collected June 1983 and submitted 1984 by A. Kośko.

Comment (A.K.): Dates the beginning of traces of southeastern European influences on Polish Lowland cultures (Kośko 1981a).

Gd-2472. Opatowice 3/21

$4570 \pm 80$

From the fill of Pit 21; depth 70-150 cm. Collected 1985 by P. Makarowicz; submitted October 1985 by A. Kośko.

Comment (A.K.): Dates the classical phase of the Radziej6w group of the Funnel Beaker culture.

Gd-1799. Jezuicka Struga 17-V/4

$7530 \pm 70$

Charcoal from remnants of a pillar in the center of Object 4, Trench V, Site 17 in Jezuicka Struga $\left(52^{\circ} 56 \mathrm{~N}, 18^{\circ} 18^{\mathrm{E}} \mathrm{)}\right)$ near Rojewo, Bydgoszcz district, Toruń Basin. Collected July 1984 by D. Prinke; submitted September 1984 by A. Kośko.

Gd-2151. Korzecznik 6/7 \#17/18

$4890 \pm 100$

Charred wood from a half-dugout of a Late Neolithic settlement in Korzecznik $\left(52^{\circ} 19 \mathrm{~N}, 18^{\circ} 47^{\prime} \mathrm{E}\right)$ near Kłodawa, Konin district, Kujawy Lakeland. The sample is from two collections of charcoal in the fill of Object 12, Trench VII, Site 6/7; depth 40-60 cm. Collected July 1981 by J. Czebreszczuk; submitted October 1983 by A. Kośko.

Comment (A.K.): Dated to establish the decline of Neolithic cultures in the Kujawy region (Kośko 1979). 
Gd-2152. Stara Wieś 9A:212/9B/2680

$5820 \pm 90$

Single pieces of charcoal from the center of dwelling pit at depth $30-60 \mathrm{~cm}$, Site $9 \mathrm{~A}$ of a Neolithic settlement in Stara Wieś $\left(52^{\circ} 55 \mathrm{~N}, 18^{\circ} 15^{\prime} \mathrm{E}\right)$ near Rojewo, district Bydgoszcz, Toruń-Eberswald Pradolina. Collected 1983 by M. Szmyt; submitted 1983 by A. Cofta-Broniewska.

Comment (A.C.B.): Dated to establish a chronology of influences of the Single Grave culture in the Kujawy region (Kośko 1979).

Gd-1985. Inowrocław $95 / 1830$

$4930 \pm 70$

Collagen from human bones from the grave of the Funnel Beaker culture, Site 95 in Inowrocław $\left(52^{\circ} 46^{\prime} \mathrm{N}, 18^{\circ} 15^{\prime} \mathrm{E}\right)$, district Bydgoszcz, Kujawy Plateau. Collected July 1979 by J. Bednarczyk; submitted 1985 by A. Kośko.

Gd-1983. Krusza Podlotowa 2/31

$4250 \pm 70$

Collagen from an animal bone from Site 2 in Krusza Podlotowa $\left(52^{\circ} 46^{\prime} \mathrm{N}, 18^{\circ} 14^{\prime} \mathrm{E}\right)$ near Inowrocław, district Bydgoszcz, Kujawy Plateau. The site is located in black soil cover of the lower terrace of the Noteć River Pradolina. Object 31 with animal bones and stones has the shape of a shallow pit ca. $20 \mathrm{~m}$ long with several collections of bones at depth 40-60 cm. Collected September 1985 by P. Chachlikowski; submitted by A. Kośko.

Comment (A.K.): Dates final phase of the Radziejów group of Funnel Beaker culture; the date is consistent with Gd-2472, $4570 \pm 80 \mathrm{BP}$, corresponding to the classical phase of this group (Kośko 1981b).

\section{Lagiewniki Series}

Charcoal from pits in late phase settlement of the Funnel Beaker culture in Łagiewniki (52 $39 \mathrm{~N}, 18^{\circ}$ $18^{\prime}$ E), near Kruszwica, Bydgoszcz district, Kujawy Upland. Collected July 1977 by L. Czerniak; submitted June 1980 by $\mathrm{T}$. Wiślański.

Gd-814. Lagiewniki 5A ob. 45

$4630 \pm 60$

From a storage pit, Object 45 , Site $5 \mathrm{~A}$.

Comment (T.W.): Dates the latest phase of the Funnel Beaker culture, the Radziejów group (Kośko 1981b).

Gd-1276. Lagiewniki 3 ob. 29

$4620 \pm 50$

From the base of a grave pit, Object 29, Site 3; depth 100-120 cm.

Gd-813. Lagiewniki 3 ob. 40

$4500 \pm 110$

From the base of a refuse pit, Object 40, Site 3; depth $90 \mathrm{~cm}$.

Comment (T.W.): Site 3 contains artifacts of the Funnel Beaker culture with influences from the "southeastern European factor" (Kośko 1981a).

Gd-2222. Lisewo L-31/439

$5750 \pm 510$

Charcoal from a storage pit, Object 4 , depth $30-40 \mathrm{~cm}$, Site 31 of the Funnel Beaker culture in Lisewo $\left(53^{\circ} 18^{\prime} \mathrm{N}, 18^{\circ} 41^{\mathrm{E}} \mathrm{E}\right)$, Torun district, Chełmińskie Lakeland. Collected 1983 and submitted 1984 by S. Kukawka, Institute of Archaeology and Ethnography, Mikołaj Kopernik University, Toruń.

Comment (M.F.P.): Very small sample, diluted with inactive $\mathrm{CO}_{2}$ for counting. 
Gd-886. Zawada $1 / 80$

$5710 \pm 120$

Charcoal, part of a burned log from a palisade of a fortified settlement, Site 1, Trench 52, Object 32, depth $55 \mathrm{~cm}$. This site, with several cultural levels, is located in Zawada $\left(50^{\circ} 28 \mathrm{~N}, 21^{\circ} 20^{\prime} \mathrm{E}\right)$ near Połaniec, Tarnobrzeg district. It was intensively occupied by the Tarnobrzeg group of the Lusatian culture. Collected 1980 and submitted March 1981 by J. Michalski, Institute of Archaeology, Warsaw University, Warsaw.

Comment (J.M.): The date is older than expected; Kanwiszer and Trzeciak (1984) published a series of dates confirming the Lusatian occupation.

\section{Gródek Nadbużny Series}

Charcoal from a Neolithic settlement situated on loess inselberg on a terrace of the Bug River in Gródek Nadbużny $\left(50^{\circ} 48 \mathrm{~N}, 23^{\circ} 27^{\mathrm{E}}\right)$ near Hrubieszów, Zamość district, Wolhynia Upland. Excavations at Site $1 \mathrm{C}$ resulted in the discovery of several phases of Neolithic occupation, associated with the Funnel Beaker (FB) and Wolhynia-Lublin Painted Pottery (WLPP) cultures and the LengyelPolgar Cycle (LPC). Collected 1983, 1984 and 1985 and submitted 1985 by S. Jastrzębski, Department of Archaeology, Maria Curie Skłodowska University, Lublin.

Gd-2160. G1C ob.2/83 s\#1

From the center of Pit 2/83, Trench I/83, depth $80 \mathrm{~cm}, \mathrm{FB}$ culture.

$5010 \pm 110$

Gd-2163. G1C ob.2/83 s\#2

From the lower layer of the same pit, depth $100 \mathrm{~cm}$.

$5030 \pm 90$

Gd-1918. G1C ob.7/83

$4750 \pm 50$

From the base of Pit 7/83, associated with a fragment of baked red clay, depth $120 \mathrm{~cm}$, FB culture.

Gd-2441. G1C ob. 13D/84

$4830 \pm 90$

From Layer II containing numerous shells of bivalves with animal bones and dispersed charcoal, Pit 13D/84, Trench II/84, depth $100 \mathrm{~cm}$, associated with artifacts characteristic of the FB culture and the late phase of LPC.

Gd-2454. G1C ob. 13E/84

From Layer IV, Pit 13E/84, depth 70-90 cm, associated with pottery of the FB culture.

Gd-2455. G1C ob.13F/84

From Layer IV, base of Pit 13F/84, depth $160 \mathrm{~cm}, \mathrm{FB}$ culture.

$4840 \pm 120$

$\begin{array}{ll}\text { Gd-2442. G1C ob.18C/84 } & 4530 \pm 70\end{array}$

$4330 \pm 80$

From Layer V at the base of Pit $18 \mathrm{C} / 84$, depth $140 \mathrm{~cm}$, associated with baked clay and numerous fragments of pottery of the FB culture.

Gd-2440. G1C ob.10/85

From Layer V at the base of Pit 10/85, depth $100 \mathrm{~cm}, \mathrm{FB}$ culture.

Gd-2427. G1C ob.22/85

From the fill of Pit 22/85, Trench I/85, depth $150 \mathrm{~cm}$, FB culture.

$4580 \pm 90$

Gd-2468. G1C s\#25/85

From the fill of a ditch, the upper part of Layer II, depth $110 \mathrm{~cm}$.

Gd-2439. G1C s\$27/85

$5110 \pm 60$

From the fills of the same ditch, Layer V, depth $200 \mathrm{~cm}$. 
Comments (S.J. and M.F.P.): The ditch is associated with the WLPP culture and is intersected by some pits associated with the FB culture. For a general outline of the chronology of the southeastern group of the FB culture, see Wiślański (1979); details of earlier excavations are described by Kowalczyk (1968). A general outline of the WLPP culture is given by Gurba (1974); elements of other cultures in this site are discussed by Kempisty (1962) and Poklewski (1958).

\section{Sandomierz Series}

Charcoal from Neolithic sites on a loess hill in Sandomierz $\left(50^{\circ} 40^{\prime} \mathrm{N}, 21^{\circ} 45^{\prime} \mathrm{E}\right)$, Tarnobrzeg district, Sandomierz Upland. Collected 1980 and 1982 and submitted 1982 and 1983 by H. KowalewskaMarszałek, Institute of the History of Material Culture, Polish Academy of Sciences, Warsaw.

Gd 984. Żmigród

$5110 \pm 140$

From the fill of Pit 3, depth $15-35 \mathrm{~cm}$.

Gd-2040. Wzgórze Zawichojskie ob.4

$5090 \pm 100$

From the fill of a ditch, Trench I/82, depth $130 \mathrm{~cm}$.

Gd-2041. Wzgórze Zawichojskie p6

$3770 \pm 70$

From the fill of Pit 6, Trench I/82, depth 40-75 cm.

Comment (H.K.M.): The first two samples are associated with the LPC of the Early/Middle Neolithic; the third is associated with the Mierzanowice culture dated to the end of the Neolithic/ beginning of the Early Bronze Age. For a general reference, see Kruk (1973) and Kulczycka-Leciejewiczowa (1979).

\section{Las Stocki Series}

Charcoal from the settlement of Wolhynia-Lublin Painted Pottery culture (Gurba 1974), Site 7 in Las Stocki $\left(51^{\circ} 20^{\prime} \mathrm{N}, 22^{\circ} 3^{\prime} \mathrm{E}\right)$ near Końskowola, Lublin district, on the loess cover of the Nałęczów Plateau, ca. $175 \mathrm{~m}$ asl. Collected 1982 and 1983 and submitted May 1984 by A. Zakościelna, Department of Archaeology, Maria Curie Skłodowska University, Lublin.

Gd-2204. LS 7/5-XI

$4990 \pm 100$

Burning layer XI at the base of Pit 5, depth $120-130 \mathrm{~cm}$.

Gd-2205. LS 7/19-IX

$5020 \pm 110$

From cultural layer IX at the base of a pit below dwelling object 19, depth $130-140 \mathrm{~cm}$.

Gd-1723. LS 7/36-V

$\mathbf{5 0 3 0} \pm \mathbf{5 0}$

From cultural layer $\mathrm{V}$ at the base of Pit 36 , depth $65-70 \mathrm{~cm}$.

Gd-1724. LS 7/28-X

$5350 \pm 60$

From cultural layer $X$ at the base of Pit 28, depth $120 \mathrm{~cm}$.

Comment (A.Z.): The expected age was $3200-3000 \mathrm{BC}$ for this series, which fits well with a previous ${ }^{14} \mathrm{C}$ date of the WLPP settlement in Wawolnica, Nałęczów Plateau $5070 \pm 210 \mathrm{BP}$, Lod 178 (Kanwiszer and Trzeciak 1986). Wiślański (1979) compared pottery assemblages with other sites in the area.

\section{Pałecznica Series}

Charcoal from a Late Neolithic site in Pałecznica $\left(50^{\circ} 14 \mathrm{~N}, 20^{\circ} 18 \mathrm{E}\right)$, Kielce district, Miechów Upland, at the top of a loess hill. Collected August 1983 and submitted November 1983 by Z. Liguzińska Kruk, Institute of the History of Material Culture, Polish Academy of Sciences, Kraków. 
Gd-1673. Pałecznica \#6

From a channel with traces of wooden beams surrounding a mound, depth $60-70 \mathrm{~cm}$.

$3590 \pm 40$

Gd-2156. Pałecznica \#7

From a layer at the top of a grave.

$320 \pm 60$

Comment (Z.L.K.): Gd-1673 dates the oldest phase of the Corded Ware culture in southern Poland (Machnik 1966, 1978); Gd-2156 is obviously erroneous.

Gd-2428. Wichorze 24/1/2

$4340 \pm 90$

Charcoal from the basal layer at depth $1 \mathrm{~m}$ in a midden pit associated with the Globular Amphora culture (KAK), Site 24, Trench 1, Object 2, atop a hill in the valley floor of the Struga Żacka River in Wichorze $\left(53^{\circ} 18^{\prime} \mathrm{N}, 18^{\circ} 32^{\prime} \mathrm{E}\right)$, near Stolno Village, Torun district, Chełmińskie Lakeland. Collected and submitted 1984 by R. Kirkowski.

Comment (R.K.): Dated to establish a chronology of habitation of KAK groups in Chełmińskie Lakeland; expected age: 2400-2600 BC (Bednarczyk et al. 1975).

\section{BRONZE AGE}

Gd-2297. Topólka R14/263

$3470 \pm 80$

Charcoal from the center of a furnace pit at depth $60-80 \mathrm{~cm}$, Object 9 of Bronze Age settlement in Topólka ( $\left.52^{\circ} 30 \mathrm{~N}, 18^{\circ} 14^{\prime} \mathrm{E}\right)$, district Włocławek, Kujawy Lakeland. Collected July 1984 by J. Czebreszczuk; submitted August 1984 by A. Kośko.

Comment (A.K.): The date fits fairly well with the Early Bronze Age chronology established for the Kujawy region (Kośko 1979).

Gd-2289. Narkowo N9/236

$3290 \pm 90$

Charcoal from the center of a hearth at depth $40-60 \mathrm{~cm}$ in Object 1 (furnace pit?) of a Bronze Age settlement, Site 9 in Narkowo $\left(52^{\circ} 40^{\prime} \mathrm{N}, 18^{\circ} 35^{\prime} \mathrm{E}\right)$ near Dobre, district Włocławek, Kujawy Plateau. Collected August 1984 by J. Czebreszczuk; submitted August 1984 by A. Kośko.

Comment (A.K.): Associated material shows first traces of features typical for the Lusatian culture (Kośko 1979).

Gd-1684. Podgaj 6A/3374

$3840 \pm 70$
Collagen from human bones from the base of a grave pit, Object 62, Site 6A of the Bronze Age in Podgaj $\left(52^{\circ} 50^{\prime} \mathrm{N}, 18^{\circ} 37^{\prime} \mathrm{E}\right)$ near Aleksandrów Kujawski, district Włocławek, Kujawy Plateau. Collected August 1982 by P. Chachlikowski; submitted June 1983 by A. Cofta-Broniewska, Institute of Prehistory, Adam Mickiewicz University, Poznań.

Comment (A.C.-B.): Dated to establish a chronology of EB Epi-Corded Ware groups of the Polish Lowlands.

\section{Bożejewice Series}

Charcoal and collagen from human bones from a Bronze Age settlement in Bożejewice, Site 8 $\left(52^{\circ} 36^{\prime} \mathrm{N}, 18^{\circ} 10^{\prime} \mathrm{E}\right)$ near Strzelno, district Bydgoszcz, Kujawy Plateau. Collected July and August 1980 and submitted May 1981 and June 1983 by A. Kośko.

Gd-888. B8/2251

Charcoal from a burned bow at the base of a burial pit, Object 32, depth $2 \mathrm{~m}$.

$4140 \pm 120$ 
Gd-1349. B8/2257

Charred wood from a coffin made of a single tree trunk ("log grave"), Object 2, depth $80 \mathrm{~cm}$.

Gd-2171. B8/10822

Human bone from a grave pit, Object 5 , depth $40 \mathrm{~cm}$.

$2850 \pm 80$

Comment (A.K.): Boundary of the 2nd and 3rd periods of the Bronze Age; sample dates the beginning of the Lusatian culture in the Kujawy region.

Gd-3025. B8/10852

Human bones from a grave pit, Object 24, depth $c a .60 \mathrm{~cm}$.

$\mathbf{3 7 7 0} \pm \mathbf{5 0}$

Gd-2499. B8/10852bis

Repeat run of Gd-3025.

$3760 \pm 120$

Comment (M.F.P.): Collagen extracted in 1981 was stored in glass jar for four years.

\section{Gd-2462. Krusza Zamkowa 16/2350}

$2860 \pm 80$

Charcoal found at depth $50 \mathrm{~cm}$ between stones surrounding a grave in Krusza Zamkowa, Site 16 $\left(52^{\circ} 45^{\prime} \mathrm{N}, 18^{\circ} 12^{\prime} \mathrm{E}\right)$ near Inowrocław, district Bydgoszcz, Kujawy Plateau. Collected 1981 by M. Klundner; submitted 1985 by A. Kośko.

Comment (A.K.): Gd-2462 dates regressive forms of non-chamber graves discovered in an area of black soils on the Kujawy Plateau (Kośko 1976).

\section{Siciny Series}

Charcoal and human bones from Bronze Age graves, Site 5, in Siciny $\left(51^{\circ} 45^{\prime} \mathrm{N}, 16^{\circ} 32^{\prime} \mathrm{E}\right)$, near Niechlow, Leszno district, Great Poland Lowland. Collected and submitted by T. Wiślański, Institute of the History of Material Culture, Polish Academy of Sciences, Poznań.

Gd-1166. Siciny 5 gr.17\#49

Charcoal from cremation burial 17, depth 60-80 cm. Collected and submitted 1979.

$3620 \pm 60$

Comment (T.W.): Grave belongs to a well-developed phase of the Unietyce culture, I/II period of the Bronze Age.

Gd-2111. Siciny 5 gr.1\#1

Gd-2164. Siciny 5 gr.1\#2

$3610 \pm 80$

$3460 \pm 70$

Collagen from human bones of two skeletons from Grave 1 associated with a late phase of the FB culture, in a deep pit with a stony pavement, depth $120-130 \mathrm{~cm}$. Collected 1978 and submitted 1982.

Gd-2165. Siciny 5 gr.13\#A

$3340 \pm 90$

Collagen from a poorly preserved human skeleton found at the base of Grave 13, depth 120-130 $\mathrm{cm}$, underlying a pit of the Lusatian culture. Collected 1979 and submitted 1982.

Comment (T.W.): Gd-2165 is a unique set of copper artifacts and dates the final phase of the Bandkeramic culture.

Gd-388. Siedlnica S-6/2-II/75

$3590 \pm 110$

Charcoal from a hearth in a dwelling of fishing and hunting population in Siedlnica $\left(51^{\circ} 45 \mathrm{~N}\right.$, $16^{\circ} 21 \mathrm{E}$ ), near Wschowa, a terrace of the Kopanica River, Great Poland Lowland. Collected and submitted 1975 by Z. Bagniewski, Institute of Archaeology, Wrocław University, Wrocław.

Comment (Z.B.): Gd-388 is much younger than expected; the site is archaeologically dated to the end of the Boreal. 


\section{Gołdap Series}

Charcoal from cultural layers of Site Ic in Gołdap $\left(54^{\circ} 20 \mathrm{~N}, 22^{\circ} 20^{\prime} \mathrm{E}\right)$, Mazury Lakeland, northeast Poland. Collected 1972 and 1973 and submitted 1982 by J. Trzeciakowski.

Gd-2031. Goldap Ic, layer $1 / 1$

$2460 \pm 100$

Gd-2032. Goldap Ic, layer $1 / 2$

$1570 \pm 60$

\section{Nieborowa Series}

Charcoal from single hearths associated with mixed cultural material in Nieborowa $\left(51^{\circ} 20 \mathrm{~N}, 23^{\circ} 29^{\prime}\right.$ E), near Bukowa Wielka Village, Chełm Lubelski district. The site is located in a denudational valley on a slope of fluvioglacial hill Pagór Uhruski. Samples from Site I collected 1967 and 1968 and submitted 1979; from Site II, collected 1977 and submitted 1982 by H. Mackiewicz, Institute of the History of Material Culture, Polish Academy of Sciences, Warsaw.

Gd-1163. NbI/5B

$1390 \pm 60$

From remains of a hut in an alluvial layer of sandy soil, Site I, Trench 5, depth 80-100 cm.

Gd-1161. NbI/6A

$7120 \pm 70$

Hearth at depth $45-60 \mathrm{~cm}$, Site I, Trench 6.

Gd-1160. NbI/7A

$870 \pm 40$

Hearth at depth 60-70 cm, Site I, Trench 7.

Gd-1162. NbI/9A

$6750 \pm 70$

Hearth at depth $30-40 \mathrm{~cm}$, Site I, Trench 9.

Gd-1528. NbII/1H

$930 \pm 60$

From a burned $\log$ at depth $80-90 \mathrm{~cm}$, Site II, Trench 1 .

Gd-1529. NbII/1G

$520 \pm 60$

Hearth at depth $35-70 \mathrm{~cm}$, same location.

Comment (M.F.P. \& H.M.): Other dates from Site I: Le-335, $8250 \pm 160$; TF-754, $2680 \pm 100$; for earlier dates from Gliwice, see Mościcki and Zastawny (1976), Mościcki et al. (1978).

\section{Szarbia Series}

Charcoal from a pit dwelling, Site 9 on the south slope of a loess hill in Szarbia $\left(50^{\circ} 19^{\prime} \mathrm{N}, 20^{\circ} 24^{\prime} \mathrm{E}\right)$ near Skalbmierz, Kielce district, Miechów Upland. Collected 1981, 1982 and 1983 by B. Baczyńska; submitted 1982 and 1983 by J. Machnik, Institute of the History of Material Culture, Polish Academy of Sciences, Kraków.

Gd-2011. Szarbia \#72/81

$3670 \pm 60$

Trench V, Object 1, depth $95-115 \mathrm{~cm}$.

Gd-2012. Szarbia \#30/82

$3460 \pm 60$

Trench VII, Object 6, depth 120-140 cm.

Gd-2103. Szarbia \#162/82

$3680 \pm 100$

Trench VII, Object 15, depth 180-200 cm.

Gd-2104. Szarbia \#122/81

$3380 \pm 100$

Trench V, Object 14, depth 125-145 cm. 
Gd-2154. Szarbia \#70/83

$3830 \pm 110$

Trench IX, Object 29, depth 110-130 cm.

Gd-2153. Szarbia \#69/83

$3560 \pm 110$

Trench IX, Object 9, depth 130-150 cm.

Comment (J.M.): The series dates the youngest phase of the Mierzanowice culture. Another date from the same site is $3530 \pm 60 \mathrm{BP}$ : Bln-2575.

\section{Ożarów Series}

Fine charcoal lumps scattered in layers of clay, sand and debris in shafts of a flint mine in Ożarów $\left(50^{\circ} 44^{\prime} \mathrm{N}, 21^{\circ} 40^{\circ} \mathrm{E}\right)$, Tarnobrzeg district, Kielce-Sandomierz Upland. Collected 1981, 1982 and 1984; submitted 1983 and 1984 by J. Budziszewski, Institute of Archaeology, Warsaw University, Warsaw.

Gd-2108. Shaft 3 Level 9/114-154 cm

$3370 \pm 80$

Gd-2114. Shaft 3 Level 8/74-114 cm

$3520 \pm 80$

Gd-2115. Shaft 4 Level $9 / 120 \mathrm{~cm}$

$3430 \pm 80$

Gd-2449. Shaft 1 s\#1

$3710 \pm 120$

From the top of sandy scree, Trench I, Shaft 1, Levels 8 and 9, depth $25-144 \mathrm{~cm}$.

Gd-2450. Shaft E s\#41

$3440 \pm 120$

From the top of anthropogenic fill of Shaft E, Trench IV, Level 2, depth 70-125 cm.

Gd-2448. Shaft D s\#40

$3720 \pm 120$

From the top of anthropogenic fill of Shaft D, Trench IV, Levels 1 and 2, depth 50-90 cm.

Gd-2443. Shaft B s\#39

$3970 \pm 70$

From the top of sandy scree overlain by an anthropogenic layer, Trench IV, Shaft B, Levels 2 and 3, depth $105-160 \mathrm{~cm}$.

Gd-2451. Shaft L s\#60

$3580 \pm 220$

From the top of sandy scree, Trench VII, Shaft L, Level 3, depth 80-95 cm.

Comment (J.B.): Ożarów site belongs to the Mierzanowice culture from the end of the Neolithic and the beginning of the Bronze Age; expected age: $1400-1800 \mathrm{BC}$ (Machnik 1978). Other ${ }^{14} \mathrm{C}$ dates of this culture in Poland are from Polany Kolonie II (Schild, Królik and Mościbrodzka 1977) and Iwanowice (Machnik 1978).

\section{Osłonino Series}

Charcoal from a settlement of Rzucewska culture, Site 2 in Osłonino $\left(54^{\circ} 40^{\prime} \mathrm{N}, 18^{\circ} 28^{\prime} \mathrm{E}\right)$ near Puck, Gdańsk district, Kaszuby Coastal Area. The site is located on Kępa Pucka hill near the cliff shore of Puck Bay, 14 m asl. Collected by D. Król; submitted 1983 and 1984 by T. Wiślański.

Gd-1606. s\#2/80

$3930 \pm 60$

Part of a burned pile associated with pile cottage 2, Trench II/80, depth $2.68 \mathrm{~m}$; collected July 1980.

Gd-1607. s\#3/81

$3940 \pm 60$

From the south part of fill of burned pile cottage 3, Trench IIA/81, depth $2.08 \mathrm{~m}$; collected July 1981.

Gd-1752. s\#4/83

$3910 \pm 70$

From a burned pile from pile cottage 4/83, Trench X, depth 1.8 m; collected July 1983. 
Gd-3067. s\#4/83bis

Duplicate run of Gd-1752.

Comments (M.F.P. \& D.K.): Gd-3067 was dated as a check of a new proportional counter assembly (L2). The dates agree fairly well with the accepted chronology of the Rzucewska culture (Żurek 1953; Wiślański 1979; Machnik 1979).

Gd-2016. Słonowice 1

$2810 \pm 80$

Charcoal from depth 70-95 cm, Pit 8, Trench VIII, Site G in Słonowice $\left(50^{\circ} 10 \mathrm{~N}, 20^{\circ} 29^{\prime} \mathrm{E}\right)$, near Kazimierza Wielka, Kielce district, Proszowice Plateau. Collected 1982 by K. Tunia and submitted by J. Machnik. The site is located in loessy cover on the south slope of the Małoszówka River valley. Associated artifacts belong to the Trzciniecka culture of the II/III period of the Bronze Age.

Comment (K.T.): Expected age: $1500-1000$ BC.

Gd-1760. Ulucz 1/82

$2960 \pm 50$

Charcoal from the basal layer of a pit dwelling in Ulucz $\left(49^{\circ} 40 \mathrm{~N}, 22^{\circ} 16^{\mathrm{E}} \mathrm{E}\right)$, near Dydnia, Krosno district, west Carpathians. Site 3 is located on an alluvial cone of the Borownica River at its mouth to the valley of the San River. Gd-1760 is from the south of Object 13B, depth 70-110 cm, associated with pottery of the Late Bronze/Early Iron Age (Parczewski 1983). Collected 1982 and submitted 1984 by M. Parczewski, Institute of Archaeology, Jagellonian University, Kraków.

\section{IRON AGE}

\section{Psary Series}

Charcoal from basal parts of iron smelting furnaces and other features of a settlement of the Roman period associated with iron metallurgy in Psary, Site $1\left(51^{\circ} 40 \mathrm{~N}, 16^{\circ} 17^{\prime} \mathrm{E}\right)$, near Jemielno, Leszno district, Lower Silesia. The settlement covers $c a$. 20 ha with 8 smelting sites; the largest Site 1 consists of 89 iron smelting furnaces arranged in uneven rows (Mamzer 1983; Mamzer and Pazdur 1984). Collected 1982 and submitted 1983 by H. Mamzer, Institute of the History of Material Culture, Polish Academy of Sciences, Poznań.

Gd-1426. Pit \#193

$2080 \pm 50$

Gd-1427. Furnace \#55

$1950 \pm 50$

Gd-1428. Furnace \#63

$2030 \pm 60$

Gd-1429. Furnace \#71

$2110 \pm 60$

Gd-1430. Furnace \#43

$1890 \pm 50$

Gd-1431. Furnace \#76

$2030 \pm 50$

Gd-1432. Furnace \#60

$1930 \pm 60$

Gd-1633. Furnace \#185

$1910 \pm 40$

Comment (H.M. \& M.F.P.): This site is representative of a metallurgic region of Lower Silesia, consisting of $>50$ sites situated mainly between the Barycz and Odra Rivers. These results indicated that the main activity of this metallurgic center is synchroneous with the Holy Cross Mts. and Masovian centers of prehistoric iron metallurgy in Poland (Pazdur, Pazdur and Zastawny 1981; Pazdur 1990).

\section{Opole-Grotowice Series}

Wood of oak trunks from a terrace of the Odra River in Opole-Grotowice $\left(50^{\circ} 35^{\prime} \mathrm{N}, 17^{\circ} 55^{\prime} \mathrm{E}\right)$, at depth $c a .5 \mathrm{~m}$ in series of fine gravels. Collected June 1975 by W. Piszczatowski and submitted 1975 by J. Kaźmierczak, Institute of Archaeology, Wrocław University, Wrocław. 
Gd-392. OG \#1

\section{Izdebno Series}

Wood and charcoal from a fortified settlement of the Lusatian culture at a peninsula in Wolskie Lake near Izdebno ( $\left.52^{\circ} 45 \mathrm{~N}, 17^{\circ} 39^{\prime} \mathrm{E}\right), 13 \mathrm{~km}$ southwest of Żnin, Gniezno Upland, Great Polish Lowland. Collected 1979 and submitted 1985 by B. Nowaczyk, Institute of Quaternary Research, Adam Mickiewicz University, Poznań.

Gd-1184. Izdebno 79/1

Wood from an oak log from a road surrounding the settlement, presently $1.4 \mathrm{~m}$ below water level (Nowaczyk et al. 1982).

\section{Gd-717. Izdebno 79/2}

$2950 \pm 140$

Charcoal from a layer of clayey sands overlying the courtyard of the settlement, depth $1.2 \mathrm{~m}$.

Comment (B.N.): Older than expected.

\section{Smuszewo Series}

Wood and charcoal from the remains of an individual house, $80 \mathrm{~cm}$ deep, in a fortified settlement of the Lusatian culture, Early Iron Age in Smuszewo $\left(52^{\circ} 54 \mathrm{~N}, 17^{\circ} 24 \mathrm{E}\right.$ ), Piła district (Durczewski 1970). Collected 1984 by D. Durczewski and submitted 1985 by L. Krzyżaniak, Archaeological Museum, Poznań.

Gd-3171. Smuszewo 1/84 $2670 \pm 40$

Wood from a wall.

Gd-3173. Smuszewo 2/84

$2650 \pm 40$

Charcoal from the floor of a house, probably a hearth.

Gd-3172. Smuszewo 3/84

$2600 \pm 40$

Wood from the floor.

Gd-3050. Michelin M-1/262

$1810 \pm 40$

Wooden pile from an enclosure (?) on a terrace of the Wisła River in Michelin $\left(52^{\circ} 35^{\prime} \mathrm{N}, 19^{\circ} 1^{\mathrm{E}} \mathrm{E}\right)$, Site 1, near Włocławek. Collected and submitted by S. Kukawka.

Comment (S.K.): Expected age ca. $2000 \mathrm{BC}$, which is much younger than expected.

\section{Poprad River Valley Series}

Charcoal from selected sites in the valley of the Poprad River, Beskid Sądecki Mts., West Carpathians, associated with the decline of the Przeworska culture. Collected by K. Tunia and submitted 1983 by J. Machnik.

Gd-1626. Moszczenica Wyżnia A/6

Single fragments found in Pit 6, depth $30-50 \mathrm{~cm}$, Site A, situated on a watershed between the Moszczenica and Potok Przysietnicki Rivers, altitude $440 \mathrm{~m}$ asl, in Moszczenica Wyżnia (49 $30 \mathrm{~N}$, $\left.20^{\circ} 39^{\prime} \mathrm{E}\right)$ near Stary Sącz, Nowy Sącz district. Collected 1975.

Comment (K.T.): Expected age: 4th-5th centuries BC (Madyda-Legutko and Tunia 1978). 
Gd-1620. Moszczenica Wyżnia A/5

From deep Pit 5, Site A, depth 50-105 cm. Collected 1975.

$1400 \pm 60$

Gd-1609. Moszczenica Wyżnia C/11

From Pit 11, depth 30-70 cm, Site C. Collected 1976.

$650 \pm 40$

\section{Gd-1619. Piwniczna A/2}

$1770 \pm 50$

From Pit 2, depth $20-40 \mathrm{~cm}$, Site A, located at the drainage of a watershed between the Poprad and Łomniczanka Rivers, altitude $c a .600 \mathrm{~m}$ asl, in Piwniczna (49 $\left.26 \mathrm{~N}, 20^{\circ} 43^{\prime} \mathrm{E}\right)$. Collected 1977.

Gd-1618. Rytro A/13a

From Pit 13a, depth 30-40 cm Site A, located at the drainage $\quad \mathbf{8 2 0} \pm \mathbf{5 0}$ the Poprad River, altitude $490 \mathrm{~m}$, Site A, located at the drainage of a watershed on the west bank of the Poprad River, altitude $490 \mathrm{~m}$ asl, in Rytro (49 $\left.29 \mathrm{~N}, 20^{\circ} 40 \mathrm{E}\right)$. Collected 1981.

\section{MidDLE AGES}

\section{Pułtusk Series}

Organic remains from Level V in a medieval castle (Gołembnik 1985) in Pułtusk $\left(52^{\circ} 43^{\prime} \mathrm{N}, 21^{\circ} 5^{\prime} \mathrm{E}\right)$. Collected and submitted 1979 by A. Gołembnik, Warsaw.

Gd-699. PI, organic remains, $422 \mathrm{~cm}$

Gd-1174. PII, straw, 429 cm $850 \pm 60$

Gd-1175. PIII, wood from hut, $416 \mathrm{~cm}$

Gd-1173. PIV, chopped straw, $420 \mathrm{~cm}$ $780 \pm 60$

Gd-1172. PV, moss, $421 \mathrm{~cm}$

Orle Series

$830 \pm 60$

$960 \pm 60$

Wood from two piles found in a vertical position in Site I in Orle $\left(54^{\circ} 39^{\prime} \mathrm{N}, 18^{\circ} 9^{\prime} \mathrm{E}\right)$, near Wejherowo, Gdansk district, in Reda-Łeba Pradolina, south of Stare Orle Lake, at depth $125 \mathrm{~cm}$ in a layer with mollusk shells. Collected 1984 and submitted 1985 by D. Król, Archeological Museum,
Gdansk.

Gd-2331. Orle pile \#1

Gd-2328. Orle pile \#2

$990 \pm 100$

$1000 \pm 80$

Comment (D.K. and M.F.P.): Part of Pile 1 was dated independently at Groningen, GrN-12896: 1070 \pm 30 BP. Results agree within $\pm 1 \sigma$ confidence limits (Pazdur et al. 1986).

\section{Stradów Series}

Charcoal and burned wooden beams from a rampart of an Early Medieval castle in Stradów (50 $23^{\prime} \mathrm{N}, 20^{\circ} 30^{\prime} \mathrm{E}$ ), near Czarnocin, Kielce district (Dąbrowska 1973). Samples Gd-2013 and -2015 collected 1981 by U. Maj; the rest collected 1983 by H. Zoll-Adamikowa; submitted by J. Machnik.

Gd-2013. Stradów \#1

From a fire layer, depth $60 \mathrm{~cm}$.

$900 \pm 60$

Gd-2015. Stradów \#2

From the center of a rampart, depth $90 \mathrm{~cm}$.

$930 \pm 60$

Gd-1671. Stradów \#3

From Rampart IV, depth $15-25 \mathrm{~cm}$.

$890 \pm 40$ 
Gd-1672. Stradów \#4C

Charcoal and wood from a large beam of Rampart II, depth $10 \mathrm{~cm}$.

Gd-1674. Umianowice \#12-14/78

$880 \pm 40$

Large pieces of charcoal (Pinus silvestris L. and Quercus L. spp. (identified by M. Lityńska)) from the base of dwelling Pit 3, depth $1.2 \mathrm{~m}$, below a layer of stones, on the lower terrace of the Nida River in Umianowice $\left(50^{\circ} 36^{\prime} \mathrm{N}, 20^{\circ} 31^{\prime} \mathrm{E}\right)$ near Kije, Kielce district. Collected 1978 by W. Morawski; submitted 1983 by J. Machnik.

Comment (W.M.): Associated pottery is dated to an early phase of the Middle Ages (7th-10th century $\mathrm{AD})$.

Gd-698. Gaik 4/79

$1160 \pm 60$

Charcoal from the base of Pit 5/79, depth $1.6 \mathrm{~m}$, Layer IV with stone construction, Early Medieval pottery and animal bones, Trench 26 , on cultural hill Gaik, altitude $100 \mathrm{~m}$ asl, in Radzikowo Stare $\left(52^{\circ} 28^{\prime} \mathrm{N}, 20^{\circ} 21^{\prime} \mathrm{E}\right)$, Płock district. Collected and submitted 1979 by I. Dabrowska, Institute of the History of Material Culture, Polish Academy of Sciences, Warsaw.

Comment (I.D.): Expected age: end of 7th century AD (Gorska 1979).

Gd-3181. Gródek Leśny \#1

$1360 \pm 40$

Charcoal from a layer at depth $28-30 \mathrm{~cm}$ at the abutment of three ramparts in the Early Medieval sanctuary “Gródek Leśny" near Przysuchy Village $\left(51^{\circ} 20^{\prime} \mathrm{N}, 20^{\circ} 36^{\prime} \mathrm{E}\right)$, Radom district, Holy Cross Mts. Collected and submitted 1985 by E. Gąssowska, Heritage Protection Center, Kielce.

Gd-1902. Zamczysko \#2

$1070 \pm 50$

Charcoal, scattered at depth $30 \mathrm{~cm}$ in cult center "Góra Zamczysko" in Widełki near Daleszyce $\left(50^{\circ} 47 \mathrm{~N}, 20^{\circ} 36^{\prime} \mathrm{E}\right)$, Kielce district, Holy Cross Mts. Collected and submitted 1985 by E. Gassowska.

\section{Wyszogród Drwały Series}

Charcoal from a settlement associated with an Early Medieval castle, Site 2a in Wyszogród Drwały near Wyszogród Village $\left(52^{\circ} 23 \mathrm{~N}, 2^{\circ} 9^{\prime} \mathrm{E}\right)$, Płock district. Submitted 1984 and 1985 by W. A. Moszczyński, Institute of the History of Material Culture, Polish Academy of Sciences, Warsaw.

Gd-2283. WD 1/5B/84

$1280 \pm 130$

From the base of Object 5B/84, Layer XVI, depth $137-140 \mathrm{~cm}$, associated with a furnace and characteristic pottery dated to the beginning of the 7th century AD. Collected 1984 by M. Dulinicz.

Gd-1932. WD 18/5B/84

$1280 \pm 40$

From the same cultural layer, depth $136 \mathrm{~cm}$. Collected July 1985 by M. Dulinicz.

Gd-2280. WD 2/19/84

$1370 \pm 60$

From Object 19/84 of unknown function, Layer III, at the base of a pit, depth $55-60 \mathrm{~cm}$, associated with pottery dated to Phase I of Early Middle Ages in Mazovian Lowland, 6th century AD. Collected 1984 by W. A. Moszczyński.

Gd-1931. WD 19/25/85

$1290 \pm 35$

From a stone furnace in square dugout 25 , depth $136-140 \mathrm{~cm}$. Collected 1985 by Z. Kobyliński.

Gd-3211. WD 20/24

$1370 \pm 40$

From a niche in Object 24 , depth $40-55 \mathrm{~cm}$, associated with a unique pot with an engraving representing a rider. Collected 1985 by W. A. Moszczyński. 


\section{Białka Series}

Charcoal from two mounds in Białka Village $\left(51^{\circ} \mathrm{N}, 23^{\circ} \mathrm{E}\right)$ near Krasnystaw, Chełm district, Lublin Upland. Collected 1983 and submitted 1984 by E. Mitrus, Laboratory for Conservation of Monuments, Lublin.

Gd-1831. Białka I/1a

From small collection at the north part of Mound I, depth $60 \mathrm{~cm}$.

$1320 \pm 35$

Gd-3152. Białka $\mathrm{I} / 3$

From the center of Mound I, depth $65 \mathrm{~cm}$.

$1170 \pm 40$

Gd-3151. Białka $\mathrm{I} / 4$

From tomb pit in center of Mound I, depth $2.6 \mathrm{~m}$.

Gd-2367. Białka I/5

Small lumps found at the northern boundary of Mound I, depth $30 \mathrm{~cm}$.

Gd-3124. Białka V/24

$1240 \pm 50$

Remains of a burned wooden structure in the center of Mound V, depth $70 \mathrm{~cm}$. Collected July 1984 by B. Okupny; submitted 1985 .

\section{Kraków Kanonicza Series}

Wood (Abies alba Mill., identified by Irena Gluza) from the walls of a trench containing a collection of iron axes. In sterile sand, the trench was at a depth $120 \mathrm{~cm}$ below a recent floor of a subbasement room in House 13 at Kanonicza Street, Old City, Kraków $\left(50^{\circ} 4 \mathrm{~N}, 19^{\circ} 56 \mathrm{E}\right), c a .200 \mathrm{~m}$ north of Wawel Castle. Collected July 1979 and submitted 1981 by E. Zaitz, Archaeological Museum, Kraków.

Gd-794. P-1A

Gd-795. P-1B

$1075 \pm 120$

$1065 \pm 55$

Comment (M.F.P. and E.Z.): The collection is dated to the end of the 8th and the first half of the 9th century $\mathrm{AD}$. The samples were greatly decomposed and, during standard treatment, sample P-2 from the base of a wall was completely dissolved in alkali solution and rejected. Sample P-1A from the middle of the wall was better preserved but, because of high loss of matter, was counted after dilution with inactive gas. Sample P-1B, collected from same level as P-1A, was treated only with acid.

\section{Kraków Senacka Series}

Wooden logs from a structure of unknown function, from Early Medieval layers, Trench III, south part of the garden of the Archaeological Museum, Senacka Street, Old City, Kraków (50 $4^{\prime} \mathrm{N}, 19^{\circ}$ $56^{\prime} \mathrm{E}$ ), ca. $250 \mathrm{~m}$ north of Wawel Castle. Samples P-3 and P-4 are Quercus sp.; P-5 is Fraxinus excelsior L. (identified by Irena Gluza). Collected 1978 and submitted 1981 by E. Zaitz.

Gd-1262. P-3

Log 4 from Layer IIId, depth $260-270 \mathrm{~cm}$.

$1450 \pm 50$

Gd-1272. P-4

Log 8 from Layer IIIf, depth 283-297 cm.

$1380 \pm 45$

Gd-1273. P-5

Log 8 from Layer IIIh, depth 328-334 cm.

$1445 \pm 40$ 


\section{Kraków Rynek Series}

Charcoal from pits found below St. Wojciech Church in Rynek Główny, Old City, Kraków $\left(50^{\circ} 4\right.$ 'N, $\left.19^{\circ} 56^{\prime} \mathrm{E}\right), c a .700 \mathrm{~m}$ north of Wawel Castle. Collected 1962 and submitted 1981 by T. Radwańska, Archaeological Museum, Kraków.

Gd-797. P-6

$1680 \pm 55$

Charcoal (Pinus silvestris L., identified by Irena Gluza) from pit associated with oldest occupation layer 1, depth $280 \mathrm{~cm}$ below actual floor of the church.

Gd-796. P-7

$1360 \pm 50$

Charcoal (Alnus sp.) from a pit associated with occupation layer 2, depth $325 \mathrm{~cm}$ below the actual floor of the church.

Comment (T.R.): Both samples are archaeologically dated to the 10th century AD (Radwański 1975).

\section{Czersk Series}

Human bones and wood from a cemetery, Site 1, associated with an early medieval castle in Czersk $\left(51^{\circ} 51 \mathrm{~N}, 21^{\circ} 14^{\prime} \mathrm{E}\right)$ near Piaseczno, Warsaw district. The cemetery is located on top of a hill, ca. 20 $\mathrm{m}$ above the valley floor of the Wisła River. Graves were dug in medium-grained sands, underlying an anthropogenic layer 2.5-3 m thick. Collected during several seasons of systematic excavations (1960-1980) and submitted 1980 and 1981 by J. Rauhutowa, Institute of the History of Material Culture, Polish Academy of Sciences, Warsaw.

Gd-793. Grave 79/62-A

$1090 \pm 70$

Gd-836. Grave 79/62-L

$1025 \pm 90$

Gd-845. Grave 79/62-E

$1210 \pm 50$

Bones of the same skeleton as from Grave 79/62, Square 25B, depth $237 \mathrm{~cm}$; collected 1962.

Gd-831. Grave 113/62-L

Gd-835. Grave 113/62-E

$1040 \pm 110$

$1080 \pm 90$

Bones of the same skeleton as from Grave 113/62, Square 25BC, depth $293 \mathrm{~cm}$; collected 1962.

Gd-833. Grave 130/62-L

$1085 \pm 100$

Gd-834. Grave 130/62-E

$1150 \pm 110$

Bones of same skeleton as from Grave 130/62, Square 27C, depth $282 \mathrm{~cm}$; collected 1962.

Gd-815. Grave 678/76-W

$1235 \pm 55$

Gd-816. Grave 693/76-W

$980 \pm 65$

Highly decomposed wood, depth ca. $3 \mathrm{~m}$; collected 1976.

Gd-1810. Grave 775/80-L

$890 \pm 40$

Bone collagen, Grave 775/76, Trench 3D, depth $3 \mathrm{~m}$; collected 1980.

Gd-3098. Grave 786/80-L

$830 \pm 30$

Bone collagen, Grave 786/80, Trench 3D, depth $3 \mathrm{~m}$; collected 1980.

Gd-3102. Grave 789/80-L

$840 \pm 30$

Bone collagen, Grave 789/80, Trench 3D, depth $3.3 \mathrm{~m}$; collected 1980.

Comment (M.F.P. \& J.R.): The cemetery is archaeologically dated to the 12 th-13th centuries $\mathrm{AD}$ (Rauhutowa 1976). Bones from excavations in 1962 were used to test different procedures of collagen extraction (A-acid, L-Longin, E-EDTA, $c f$. Olsson 1979). These dates are internally consis- 
tent, but older than expected, which may be explained by incomplete removal of humic contaminants. Dates Gd-1810, -3098 and -3102 are on bones from excavations in 1980, from collagen extracted according to a slightly modified Longin (1971) procedure, and are in fairly good agreement with the expected age of the cemetery.

\section{HISTORICAL SAMPLES}

Gd-1665. Cedynia 11/1

$1070 \pm 50$

Charcoal from Hearth 5 at depth $30 \mathrm{~cm}$, Site 11, in Osinów Dolny near Cedynia $\left(52^{\circ} 55 \mathrm{~N}, 14^{\circ} 23^{\prime} \mathrm{E}\right)$.

Collected June 1972 by C. Kroczak; submitted 1983 by W. Filipowiak, National Museum, Szczecin.

Comment (W.L.): The site associated with a historical battle in AD 972 (Filipowiak 1973).

\section{Św. Krzyz Series}

Fragments of a corpse and wood from the putative coffin of Duke Jarema Wiśniowiecki in a crypt of Saint Krzyż Church at the top of St. Krzyż Mountain in Góry Świętokrzyskie (Holy Cross Mts.), $20 \mathrm{~km}$ east of Kielce. Collected and submitted 1981 by J. Widacki, Department of Criminology, Silesian University, Katowice.

Gd-856. JW3-coffin wood

Gd-865. JW4-bone

$530 \pm 80$

$280 \pm 200$

Comment: Very small sample, undersized, diluted.

Gd-857. JW1-interstines

Gd-852. JW2-interstines

$280 \pm 90$

$310 \pm 80$

Comment (M.F.P.): Samples were dated as part of an interdisciplinary study to check the authenticity of the corpse. ${ }^{14} \mathrm{C}$ dates do not contradict this hypothesis (Goslar, Pazdur and Pazdur 1983). Duke Jarema Wiśniowiecki died suddenly in AD 1651 at the age of 39 .

Gd-1689. Tupadły $2 / 2$

$80 \pm 40$

Collagen from a human bone from a burial of three individuals at the edge of a mound in Tupadty $\left(52^{\circ} 42^{\mathrm{N}}, 18^{\circ} 15^{\prime} \mathrm{E}\right)$ near Inowrocław, Bydgoszcz district, Kujawy Plateau. Collected 1983 and submitted by A. Kośko.

Comment (A.K.): Because of a lack of associated artifacts, this burial was expected to be either from the beginning of the second millennium BC or of historical age. Date confirms historical age of the burial, which is most probably connected with a battle near Tupadły in AD 1665.

\section{UNKNOWN OR UNCERTAIN CHRONOLOGY}

\section{Gdańsk Boats Series}

Oak wood from a stave boat and two dugouts from a collection of the Central Maritime Museum in Gdańsk (Smolarek 1991). Submitted March 1984 by M. Dyrkowa, Central Maritime Museum.

Gd-1896. Curve boat

Outermost treerings from a "curve boat" found in 1951 on the bottom of the Baltic Sea in the Gotland Deep area, $c a .40 \mathrm{~km}$ west of Libawa $\left(56^{\circ} 27 \mathrm{~N}, 19^{\circ} 25^{\prime} \mathrm{E}\right)$.

\section{Gd-1895. Long dugout}

Outermost part of a "long dugout" probably found near Gdańsk before 1914. The boat has been exhibited since 1945 in the Archaeological Museum, Gdańsk. 
Gd-3176. Greatest dugout

$1070 \pm 40$

Outermost rings from the "greatest dugout" from a collection of the Central Maritime Museum, Gdańsk; proveniences uncertain.

\section{Borkowo Series}

Pine wood from two dugouts found at the bottom of Glębokie Lake in Borkowo Village ( $54^{\circ} 20 \mathrm{~N}$, $\left.18^{\circ} 20^{\prime} \mathrm{E}\right)$, Gdańsk district. Collected 1981 by W. Urbański; submitted by M. Dyrkowa.

\section{Gd-922. Dugout I}

Gd-1424. Dugout II

$60 \pm 60$

$270 \pm 40$

Comment (M.F.P. and M.D.): Dugouts were treated with preservatives (polyethylene glycol 1500); samples were stored in water at ambient temperature for ten weeks before being submitted for dating; then they were subjected to standard acid-alkali-acid treatment.

\section{Tolkmicko Series}

Oak wood from fragments of two stave boats found in a meadow in Tolkmicko $\left(54^{\circ} 20^{\prime} \mathrm{N}, 19^{\circ} 31^{\mathrm{E}}\right)$. Collected 1981 by J. Kucharski; submitted by M. Dyrkowa.

$$
\begin{aligned}
& \text { Gd-920. Rib, W-15/7/80 } \\
& \text { Gd-921. Rib, Boat Ia }
\end{aligned}
$$

Gd-1212. Wreck W-18

Oak wood from the rib of the wreck of stave boat W-18 found in basal sediments at the mouth of the Wisła River $\left(54^{\circ} 22 \mathrm{~N}, 18^{\circ} 56^{\prime} \mathrm{E}\right), \mathrm{ca} .7 \mathrm{~m}$ below water level. Collected 1980 by M. Iżewski; submitted by M. Dyrkowa.

Comment (M.D.): The boat is typologically dated to the Middle Ages.

\section{Gd-1213. Czarnowsko II boat}

$1000 \pm 90$

Oak wood from the keel of a stave boat found in a meadow near Czarnowsko Village (54 $45 \mathrm{~N}$, $17^{\circ} 20 \mathrm{E}$ ), at depth $30 \mathrm{~cm}, \mathrm{ca} .250 \mathrm{~m}$ south of Łeba Lake shore. Collected 1980 by M. Iżewski; submitted by M. Dyrkowa.

Comment (M.D.): Typologically dated to the 12 th century AD.

\section{Gd-2064. Ulanów-Sudoły dugout}

Oak wood from a dugout found in San River deposits at depth $70 \mathrm{~cm}$ in Ulanow-Sudoły $\left(50^{\circ} 34 \mathrm{~N}\right.$, $22^{\circ} 4^{\prime} \mathrm{E}$ ), Sandomierz Basin, southeast of Stalowa Wola. Collected 1983 by Z. Kocur; submitted by M. Dyrkowa.

\section{Gd-2230. Ląd boat}

Oak wood from rib 13 of a stave boat found in the Warta River floodplain at depth $2 \mathrm{~m}$ at the foot of a rampart of a medieval castle in Lad $\left(52^{\circ} 10 \mathrm{~N}, 17^{\circ} 50^{\mathrm{E}} \mathrm{E}\right)$, Konin district, Great Poland Lowland. Collected 1984 by M. Brucki and submitted by M. Dyrkowa.

Comment (M.D.): This is the first stave boat found inland in Poland. 


\section{REFERENCES}

Bednarczyk, J., Koskko, A., Krawe, E. and Makiewicz, T. 1975 Studies on the final phase of the Globular Amphora Culture in Cuiavia. Settlements of the Globular Amphora culture in the trough of Pakoskie Lake. Wiadomosci Archeologiczne 40(3): 275-289 (in Polish).

Chmielewska, H. 1954 A Tardenoise culture grave in Janislawice, Skierniewice District. Wiadomości Archeologiczne 20(1): 23-48 (in Polish).

Czerniak, L. 1980 Societal Development of the Late Bandkeramic Cultures in Cuiavia. Poznań, Adam Mickiewicz University Press (in Polish).

Dabrowska, E. 1973 Great Fortified Settlements in the Upper Vistula Basin. Wroclaw-Warsaw-Kraków-Gdansk, Ossolineum (in Polish).

Dąbrowski, M. 1981 Pollen analysis of the Całowanie peat bog. Archeologia Polski 26(2) (in Polish).

Durczewski, D. 1970 An Early Slavonic Fortified Settlement in Smuszewo. Poznań, Muzeum Archeologiczne (in Polish).

Filipowiak, W. 1973 Economic and Political Significance of Cedynia at the Beginning of the Polish State. Szczecin, Muzeum Narodowe (in Polish).

Gołembnik, A. 1985 The excavations in the castle hill in Pułtusk: New directions in archaeological research. In Edgren, T. and Jungner, H., eds, Application of Scientific Methods in Archaeology. Helsinki, National Board of Antiquities: 15-22.

Górska, I. 1979 Fortified Settlements of Mazowsze and Podlasie. Wroclaw-Warszawa-Kraków-Gdansk, Ossolineum (in Polish).

Goslar, E., Pazdur, A. and Pazdur, M. F. 1983 An attempt at radiocarbon dating the suspected corpse of Duke Jarema Wisniowiecki. Archiwum Medycyny Sadowej 32: 77-80 (in Polish).

Gurba, J. 1974 The Wolhynia-Lublin Painted Pottery culture. Annales UMCS 28: 83-94 (in Polish).

Kanwiszer, A. and Trzeciak, P. 1984 Lodz radiocarbon dates I. Radiocarbon 26(1): 111-126.

1986 Lódź radiocarbon dates II. Radiocarbon 28(3): 1102-1209.

Kempisty, A. and Sulgostowska, Z. 1976 The first Neolithic settlement with pottery of the Dubiczaj type in northeastern Poland. Wiadomosci Archeologiczne 41: 305-324.

Kempisty, E. 1962 Discovery of a Bandkeramic culture grave near Lublin, in Gródek Nadbużny, Hrubieszów District. Wiadomosci Archeologiczne 28: 284-285 (in Polish).

Kobusiewicz, M. 1980 Ausgrabungen auf einer mesolitischen und neolitischen Fundstelle bei Chwalim, Westpolen. Veroff des Museums für Ur- und Fruhgeschichte Potsdam 14/15: 337-342.

Kosko, A. 1976 A contribution to studies of the genesis and development of the Cuiavian enclave of so-called chamberless graves. Archeologia Polski 21(2): 402408 (in Polish).
1979 Cultural Development of Kujawy Communities During the Late Neolithic and Early Bronze Age. Poznań, Adam Mickiewicz University Press (in Polish).

1981 a Contribution of Southeast European Cultural Patterns to the Development of the Lowland Funnel Beaker Culture Communities. Poznań, Adam Mickiewicz University Press (in Polish).

1981b A contribution to studies of the Radziejow Group of the Funnel Beaker Culture. In Cofta-Broniewska, A., ed., Studies of the Funnel Beaker Culture in Poland. Poznań, Adam Mickiewicz University Press: 191-212 (in Polish).

Kowalczyk, J. 1968 Two assemblages dated with radiocarbon. Wiadomości Archeologiczne 33: 368-376 (in Polish).

Kruk, J. 1973 Settlement Studies in the Neolithic of the Loessy Uplands. Wroclaw-Warszaw-Kraków, Ossolineum (in Polish).

Kulczycka-Leciejewiczowa, A. 1979 Early farming communities in the territory of Poland. Cultures of the Danube Circle. In Godłowska, M., Kulczycka-Leciejewiczowa, A., Machnik, J. and Wislański, T., eds., Prehistory of Poland, Vol. II, Neolithic. WroclawWarszaw-Kraków-Gdansk, Ossolineum: 19-164 (in Polish).

Longin, R. 1971 New method of collagen extraction for radiocarbon dating. Nature 230: 241-242.

Machnik, J. 1966 Studies in Bandkeramic Cultures in the Malopolska Region. Wroclaw-Warszaw-Kraków, Ossolineum (in Polish).

1978 Frühbronzezeit Polens. Übersicht über die Kulturen und Kulturgruppen. Wroclaw-Warszaw-KrakówGdansk, Ossolineum.

1979 The Bandkeramic cultural circle. In Godłowska, M., Kulczycka-Leciejewiczowa, A., Machnik, J. and Wiśański, T., eds., Prehistory of Poland, Vol. II, Neolithic. Wroclaw-Warszaw-Kraków-Gdansk, Ossolineum: 337-412 (in Polish).

Mamzer, H. 1983 Excavations of the iron smelting settlement of the Roman period in Psary, Leszno voivodship. Sprawozdania Archeologiczne 34: 141-152 (in Polish).

Mamzer, H. and Pazdur, M. F. 1984 A chronology of the metallurgic site in Psary, Leszno voivodship, in the light of C-14 dating. Archaeologia Polona 23: 67-85.

Moscicki, W., Pazdur A., Pazdur, M. F. and Zastawny, A. 1978 Gliwice radiocarbon dates IV. Radiocarbon 20(3): 405-415.

Moscicki, W. and Zastawny, A. 1976 Gliwice (Gdańsk) radiocarbon dates III. Radiocarbon 18(1): 50-59.

Parczewski, M. 1983 Ulucz, province of Krosno, community of Dydnia, site 3. Recherches Archéologiques de 1981. Kraków.

Pazdur, A., Awsiuk, R., Bluszcz, A., Pazdur, M. F., Walanus, A. and Zastawny, A. 1982 Gliwice radiocarbon dates VII. Radiocarbon 24(2): 171-181. 
Pazdur, A., Pazdur, M. F. and Zastawny, A. 1981 Ancient iron metallurgy in Poland in light of radiocarbon dating. Materiaty Archeologiczne 21: 87-94 (in Polish).

Pazdur, M. F. 1990 Absolute chronology of ancient iron metallurgy in Poland in light of the calibration of the radiocarbon time scale. Materiaty Archeologiczne 25: 95-104 (in Polish).

Pazdur, M. F., Awsiuk, R., Bluszcz, A., Goslar, T., Pazdur, A., Walanus, A. and Zastawny, A. 1985 Gliwice radiocarbon dates X. Radiocarbon 27(1): 52-73.

Polkewski, T. 1958 Settlement of the Funnel Beaker culture in Gródek Nadbużny, Hrubieszow District (Site 1C). Archeologia Polski 2: 235-278 (in Polish).

Radwański, K. 1975 Kraków Before Location-Spatial Development. Kraków, Muzeum Archeologiczne (in Polish).

Rauhutowa, J. 1976 Czersk in the Early Middle Ages from the 7th to 12th Centuries. Wroclaw-WarsawKraków-Gdansk, Ossolineum (in Polish).

Schild, R. 1975 The Late Paleolithic. In Chmielewski, W. and Hensel, W., eds., Prehistory of Poland, Vol. II, $\mathrm{Pa}$ leolithic and Mesolithic. Wroclaw-Warsaw-KrakówGdansk, Ossolineum: 159-338 (in Polish).
1982 Archaeological stratigraphy of inland dunes as seen from the Mazowsze region. Roczniki Gleboznawcze 33(3-4) (in Polish).

Schild, R. and Królik, H. 1981 Rydno-a final Paleolithic ochre mining complex. Przeglad Archeologiczny 29: 53-100.

Schild, R., Królik, H. and Mościbrodzka, J. 1977 A Chocolate Flint Mine from the Turn of the Neolithic and the Bronze Age in Polany Kolonie. Wroclaw-WarsawKraków-Gdansk, Ossolineum (in Polish).

Smolarek, P. 1991 The underwater investigations of the Polish Maritime Museum in Gdańsk from 1982 to 1985. Acta Universitatis Nicolai Copernici, Archeologia 15: 3-13.

Wislański, T. 1979 The formation of local farming and breeding cultures: Tribes of the Funnel Beaker culture. In Godłowska, M., Kulczycka- Leciejewiczowa, A., Machnik, J. and Wiślański, T., eds., Prehistory of Poland, Vol. II, Neolithic. Wroclaw-Warszaw-KrakówGdansk, Ossolineum: 165-260 (in Polish).

Zurek, T. 1953 A Paleolithic settlement in Rzucewo. Fontes Archaeologici Posnaniensis 4: 1-40 (in Polish). 